\title{
DESIGN OF POTTERY CRAFTSMEN'S SETTLEMENT WITH BEHAVIORAL ARCHITECTURE APPROACH (CASE STUDY: DUKUH KRAJAN, MALANG)
}

\author{
Dyah Kusuma Wardhani, Hari Purnomo, Happy Ratna Santosa \\ Department of Architecture, Institut Teknologi Sepuluh Nopember, Indonesia \\ e-mail: wardhani_1986@yahoo.com
}

\begin{abstract}
The presence of pottery industry in Dukuh Krajan a potential to home-based Industry that can be developed in Malang. But the existence of craftmen's settlement is not planned and managed well, so there are several problem that exist such as the lack of natural lighting and ventilation inside the house, kiln in the middle of the settlement pollutes the air and fire risk, and space conflict in craftmen house between domestic and economic needs. Behavioral architecture approach is used to make sure the design result based on the society's needs and behavior. This is a qualitative study which is focussed on community's social condition. Samples for this study consists of three elements, place, actors, and activity. For activity sample, data that being observed is covert behavior (collected through interviews) and overt behavior (collected through observation). The expected result is model of an alternative block plan in the pottery craftmen's settlement. Block plan design shows the arrangement of the building mass and open space in pottery craftsmen's settle-ment that can provide solutions to security and comfort of the building. Design performed on selected existing locations, existing condition and community are used as a basis for composing the design criteria.
\end{abstract}

Keywords: behavioral architecture, pottery craftmen's settlement, productive house

\begin{abstract}
ABSTRAK
Keberadaan industri gerabah di Dukuh Krajan merupakan industri potensial berbasis rumah tangga yang dikembangkan di Malang. Tetapi keberadaan permukiman pengrajin yang tidak terencana dan diatur dengan baik menimbulkan beberapa masalah seperti kekurangan cahaya alami dan ventilasi didalam rumah, perapian di tengah permukiman mencemari udara dan bahaya terhadap kebakaran. Masalah konflik ruang terjadi di dalam rumah pengrajin karena kebutuhan domestik dan ekonomi. Pendekatan arsitektur berdasarkan perilaku digunakan untuk meyakinkan hasil desain berdasarkan kebutuhan penduduk dan perilaku mereka. Penelitian kualitatif ini difokuskan ke kondisi sosial masyarakat. Sampel penelitian ini terdiri dari tiga elemen: tempat, pelaku dan aktivitas. Untuk contoh aktivitas, data yang
\end{abstract}


diobservasi dirubah kedalam perilaku (dikumpulkan melalui interview) dan melalui perilaku (dikumpulkan melalui observasi). Hasil yang diinginkan adalah sebuah model alternatif blok plan di permukiman pengrajin gerabah. Desain blok plan menunjukkan pengaturan massa bangunan dan area terbuka di permukiman pengrajin gerabah yang dapat menyediakan solusi bagi keamanan dan Kenyamanan di dalam bangunan. Desain dilakukan pada lokasi eksisting terpilih, kondisi eksisting dan komunitas digunakan sebagai dasar kriteria desain.

Kata kunci: arsitektur perilaku, permukiman pengrajin gerabah, rumah produktif

\section{INTRODUCTION}

Dukuh Krajan, Desa Pagelaran is one of pottery producer in Malang, the community's skill has been passed down through generation. The dominance of traditional pottery craftsmen in these settlements create unique characteristics of the settlements. Area of this settlements about 1.2 acres with approximately 67 households in it.It is located near the highway from the direction toward Bantur Malang, the highway is already accessible by public transport and private transport either motorcycles or cars.

Settlement orientation in Dukuh Krajan is in form of linear orientation along the streets with 4 meters width street is inside the settlement. This pottery industry in Dukuh Krajan is a potential home-based industry that need to be developed in Malang. Unfortunately the existence of pottery craftmen's settlements in Dukuh Krajan is not being planned and managed well,these things causing some problems exist.

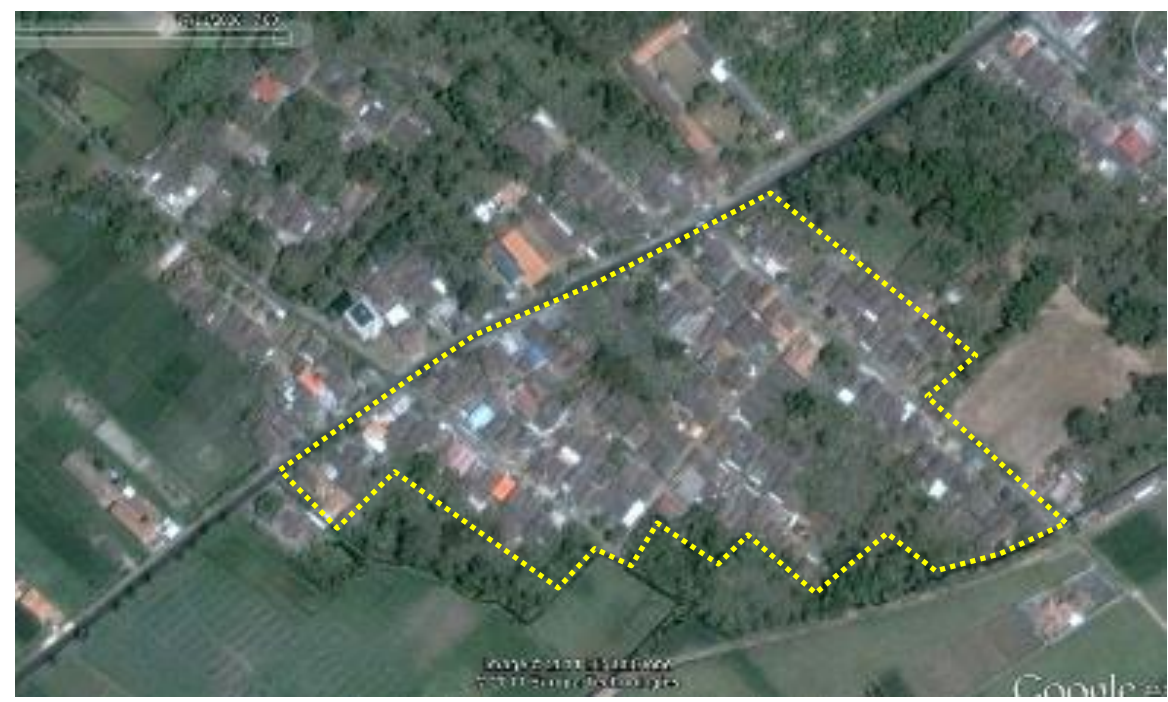

Figure 1. Selected Location Pottery Craftmen Settlement Source: google earth, 2012 

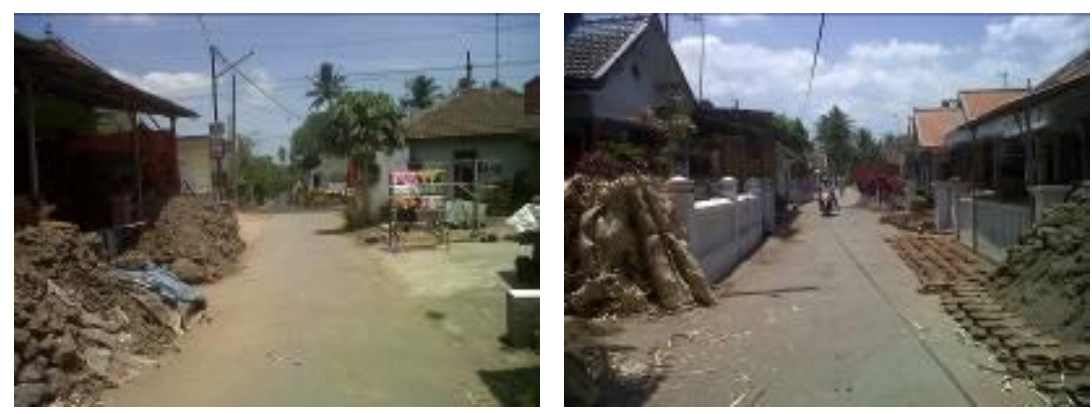

Figure 2. Along the Street Settlement Orientation Source: personal documentation, 2012

\section{THEORY/ RESEARCH METHODS}

Behavioral architecture approach is an important part for designers to start designing so that the result has a sociological dimension that is able to fullfil the behavioral patterns of the community. Through behavioral architecture in the design of pottery craftmen's settlement, the results is expected meets the needs and values of the community that use it.In this pottery craftmen's settlement design there are some physical problems that need to be resolved : space conflicts between domestic and economy needs in craftmen house. Generally the front part of the house such as yard, verandah also living room are being used as workplace, the distance between houses in the settlements is less than 1 meter causing natural lighting and ventilation is not working optimal for each house, and kiln used to burn the pottery is located in the middle of settlements, producing smoke as pollution during the combustion process and giving fire risk.

\section{RESULTS AND DISCUSSION}

\section{Behavioral Analysis as Basis for Design Criteria}

The research that recently done for this study in terms of pottery craftmen's settlement design included in qualitative research. Qualitative research is a research that research something in its natural setting, trying to understand, or interpret, in terms of the meaning given by the society (Groat and Wang, 2002). According to Spradley (1997) samples taken in qualitative research in form of social situation consists of three elements: place, actors, and activity.

Samples in the form of behavioral activity is divided into two, namely:

1. Covert behavior

An individual's response to a stimulus in the hidden or closed form (covert). Response or reaction to stimulus is limited in attention, perception, knowledge / awareness, and attitudes that occur in people who received the stimulus and can not clearly being observed by others. (Skinner, 1957) 
2. Overt behavior

An individual's response to a stimulus in the open form or action. The response to the stimulus is already evident in the form of action or practice (practice), which can easily be observed or seen by others. (Skinner, 1957)
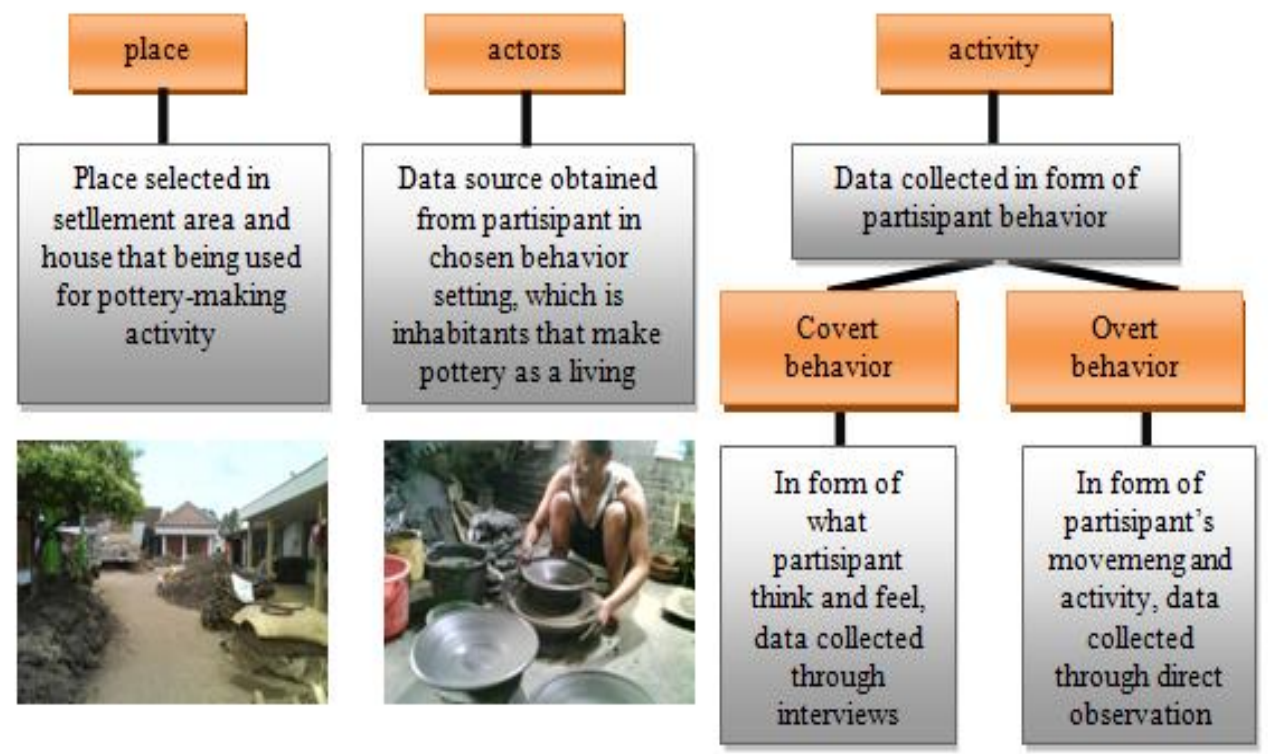

Figure 3. Samples in Terms of Pottery Craftmen's Activities Source: analysis, 2012

In terms of pottery craftmen's settlement, the three samples can be explained as follows:

1. Place (place) : settlement areas and houses that being used for pottery making activity

2. Players (actors) : inhabitants that make pottery as a living (craftmen, collector, and buyer)

3. Activity (activity) : includes covert (collected through interviews) and overt acts (collected through direct observation).

The information obtained from observations and interviews was analyzed using a Area-Role-Activity Chart as reported by Heimsath (1977) in his book Behavioral Architecture. This chart is used to determine the deeper implications of the role, furnishings or equipment, and the time period when the activity takes place. In this chart the analysis has begun to lead to things that affect the results of the design. In terms of pottery craftmen's settlement, settlement areas distinguished as three diffe-rent zones; open space in settlement, pottery craftsmen house, and pottery collectors house. 
Table 1. Area, Role, Activity Chart of Open Space in Settlement

\begin{tabular}{|c|c|c|c|c|c|}
\hline Area & Roles & Roles implication & Activity & Tools & Time frame \\
\hline Kiln & Craftmen & $\begin{array}{l}\text { 1. Need solution to } \\
\text { overcome smoke } \\
\text { pollution } \\
\text { produced during } \\
\text { the combustion } \\
\text { process } \\
\text { 2. Notice the } \\
\text { distance between } \\
\text { kiln and craftmen } \\
\text { house to reduce } \\
\text { fire risk }\end{array}$ & $\begin{array}{l}\text { used } \\
\text { interchangeably } \\
\text { by craftsmen } \\
\text { group }\end{array}$ & $\begin{array}{l}\text { Kiln, } \\
\text { Wheelba } \\
\text {-rrow }\end{array}$ & $\begin{array}{l}\text { Once in a } \\
\text { week }\end{array}$ \\
\hline $\begin{array}{l}\text { Storage } \\
\text { Area } \\
\text { (for } \\
\text { straw } \\
\text { and } \\
\text { bamboo } \\
\text { woven } \\
\text { mat) }\end{array}$ & Craftmen & $\begin{array}{l}\text { 1. Requires close } \\
\text { access to kiln } \\
\text { 2. Requires close } \\
\text { access to village } \\
\text { street, because } \\
\text { the suppliers use } \\
\text { trucks for } \\
\text { distribution } \\
\text { 3. Requires a } \\
\text { considerable } \\
\text { space dimension } \\
\text { due to the } \\
\text { irregularly } \\
\text { distribution of } \\
\text { straw and } \\
\text { bamboo mats. }\end{array}$ & $\begin{array}{l}\text { Storage of straw } \\
\text { and bamboo } \\
\text { wooven mat that } \\
\text { needed for pottery } \\
\text { combustion } \\
\text { process. }\end{array}$ & & $\begin{array}{l}\text { Irregularly } \\
\text { distribution } \\
\text { of straw and } \\
\text { bamboo } \\
\text { mats by } \\
\text { suppliers } \\
\text { about once } \\
\text { in a month. }\end{array}$ \\
\hline
\end{tabular}

Source: adapted from table Area, Role, Activity Chart, Heimsath, 1977

Open space in this settlement is in form of traditional kiln used for pottery combustion process. Near kiln there's also storage area to keep straw and bamboo mat that needed for combustion process. Dukuh Krajan as pottery craftmen's settlement has 7 traditional kiln (diameter 3-4 meter), each of it used interchangeably by $9-10$ craftmen. 

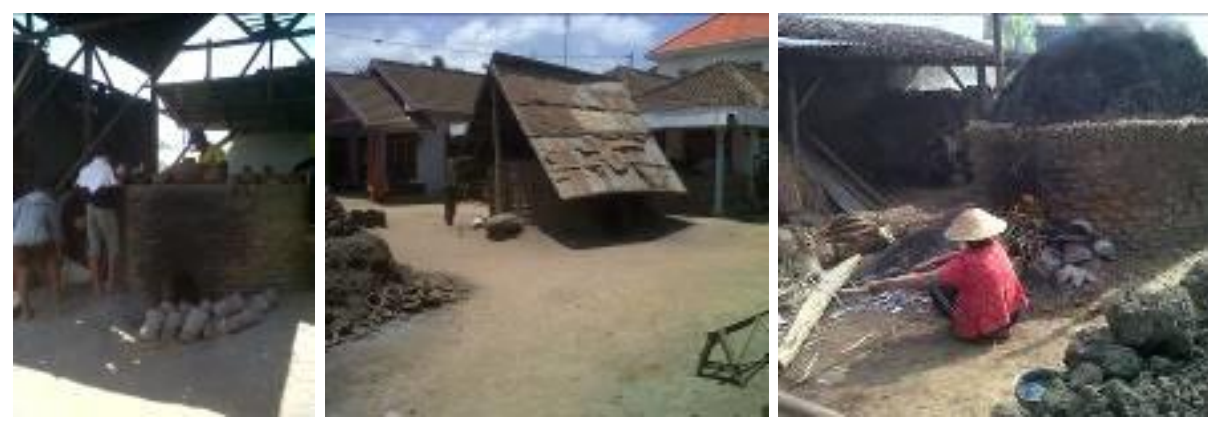

Figure 4. Traditional Kiln

Source: personal documentation, 2012
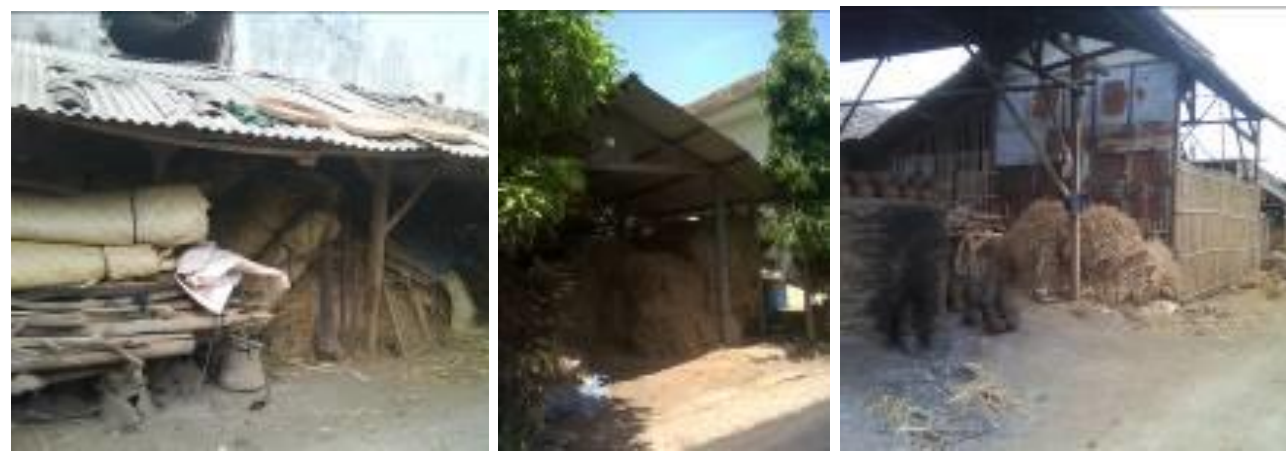

Figure 5. Storage for Straw and Bamboo Woven Material

Source: personal documentation, 2012

Table 2. Area, Role, Activity Chart of Pottery Craftmen House

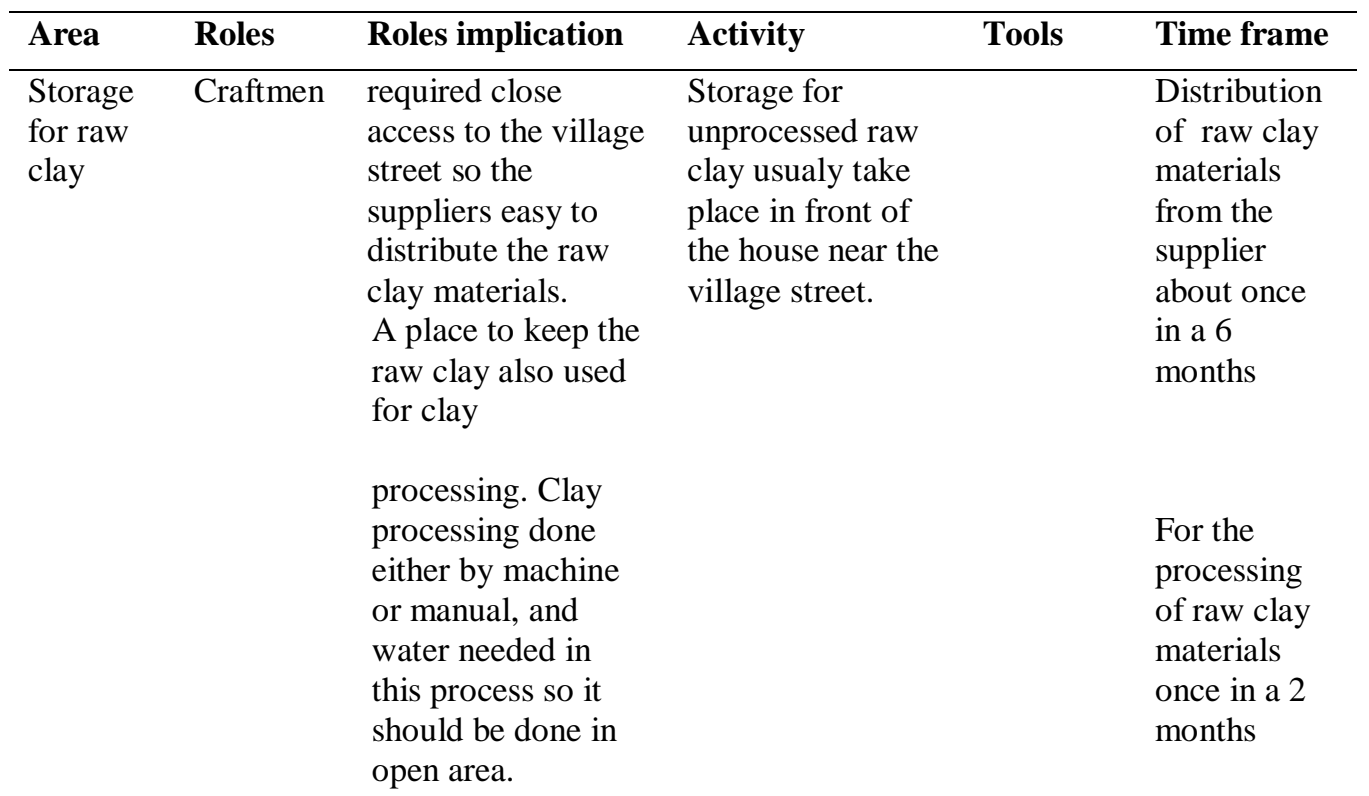


Table 2. Continue

\begin{tabular}{|c|c|c|c|c|c|}
\hline Area & Roles & Roles implication & Activity & Tools & Time frame \\
\hline $\begin{array}{l}\text { Work } \\
\text { area }\end{array}$ & Craftmen & $\begin{array}{l}\text { Done in shady part } \\
\text { of the house which } \\
\text { has optimal natural } \\
\text { lighting and } \\
\text { ventilation such as } \\
\text { in veranda, side part } \\
\text { of the house, or } \\
\text { inside the house. }\end{array}$ & $\begin{array}{l}\text { Place for clay } \\
\text { forming into } \\
\text { pottery product }\end{array}$ & $\begin{array}{l}\text { Pottery } \\
\text { forming } \\
\text { rotary } \\
\text { tool, } \\
\text { bucket, } \\
\text { wood } \\
\text { shelves }\end{array}$ & $\begin{array}{l}\text { Every day } \\
\pm 05.00- \\
12.00 \mathrm{AM}\end{array}$ \\
\hline $\begin{array}{l}\text { Pottery } \\
\text { Drying } \\
\text { Area }\end{array}$ & Craftmen & $\begin{array}{l}\text { Pottery drying is } \\
\text { done in } 2 \text { ways with } \\
\text { aerated and dried in } \\
\text { the direct sunlight. } \\
\text { Pottery aerated } \\
\text { right after } \\
\text { completed formed } \\
\text { while drying in the } \\
\text { direct sun done } \\
\text { before the pottery } \\
\text { get burned in kiln. }\end{array}$ & $\begin{array}{l}\text { Area for pottery } \\
\text { drying after } \\
\text { completed } \\
\text { formed. }\end{array}$ & $\begin{array}{l}\text { Wood } \\
\text { shelves }\end{array}$ & $\begin{array}{l}\text { Every day } \\
\pm 08.00 \text { AM - } \\
04.00 \text { PM }\end{array}$ \\
\hline $\begin{array}{l}\text { Pottery } \\
\text { Storage }\end{array}$ & Craftmen & $\begin{array}{l}\text { In existing only } \\
\text { small amount of the } \\
\text { craftmen house } \\
\text { have a special room } \\
\text { for storage, the rest } \\
\text { of it use part of the } \\
\text { house as storage. }\end{array}$ & $\begin{array}{l}\text { Place to keep } \\
\text { pottery before and } \\
\text { after burned. }\end{array}$ & & \\
\hline
\end{tabular}

According to Silas (2000), there are three types of space uses of domestic area and productive area:

1. Mixed type: domestic area together with productive area are in a house and coud not be separated. In this type, domestic function is still being dominant.

2. Balanced type: domestic area is separated with productive area but still in the same building.

3. Separated type: productive area is dominant and take the largest area from the total area in the house. Sometime, domestic area is placed behind or in front of productive area (it could be in different building).

The three types of productive house can be found in the Dukuh Krajan. Separated type productive house is owned by craftmen who has vast area of land. The other two, mixed type and balanced type, are mostly found and owned by most craftmen in Dukuh Krajan.

In separated type sample, separate work area is usually in form of simple building separate from the house with walls from bamboo woven and plywood boards. In existing only founded 3 houses that included separated type. 
In balanced type sample, usually the verandah and yard is already used for raw clay storage and pottery drying area. Workplace take place inside the house, and has a room for pottery storage. In existing there are 21 houses included in balanced type.
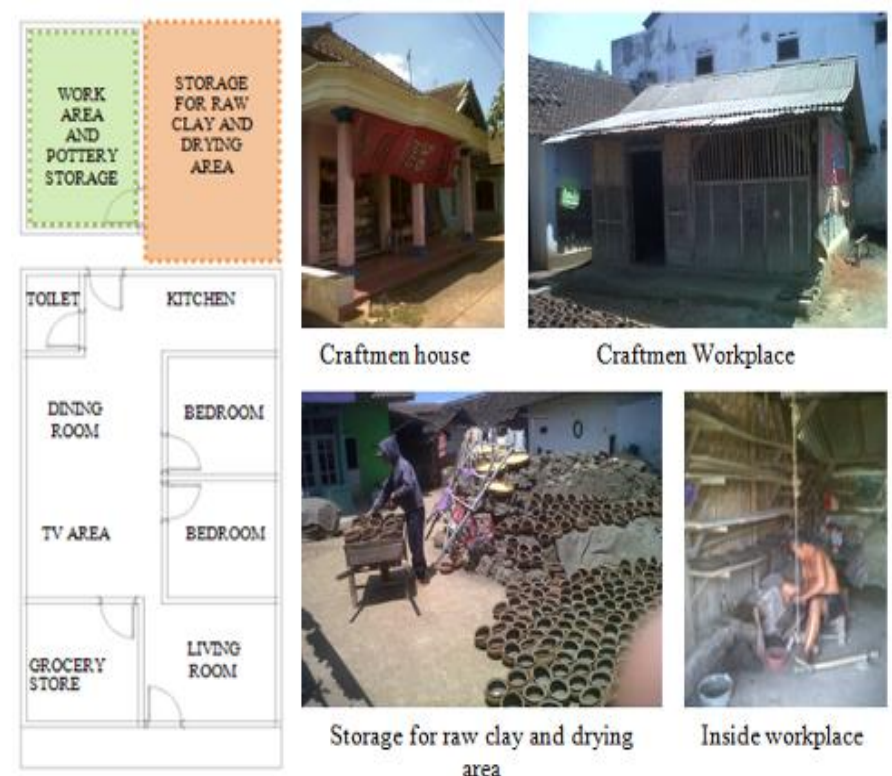

Storage for raw clay and drying area

Figure 6. Separated Type

Source: personal documentation, 2012
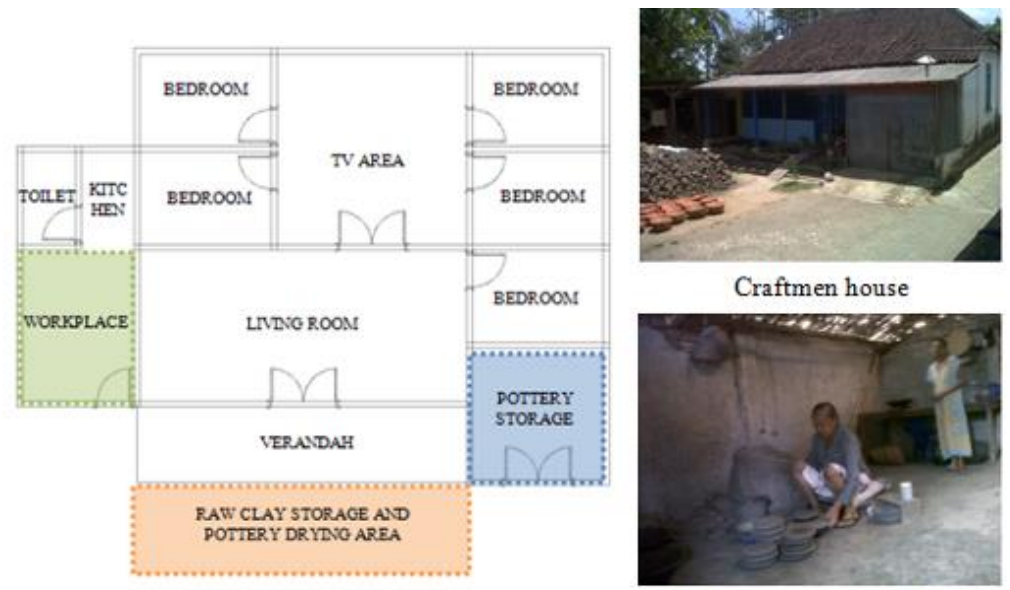

Workplace inside the house

Figure 7. Balanced Type

Source: personal documentation,2012

In mixed type sample, craftmen workplace is in front or side part of the house to overcome the limitations of space they had. Workplace that took place in front of the house usually in verandah, whereas that took place at side part of the house is in 
alley between the craftmen house. In this sample type they have no spesific room as storage, so they use some part of living room and tv area. In existing there are 39 houses included in mixed type.
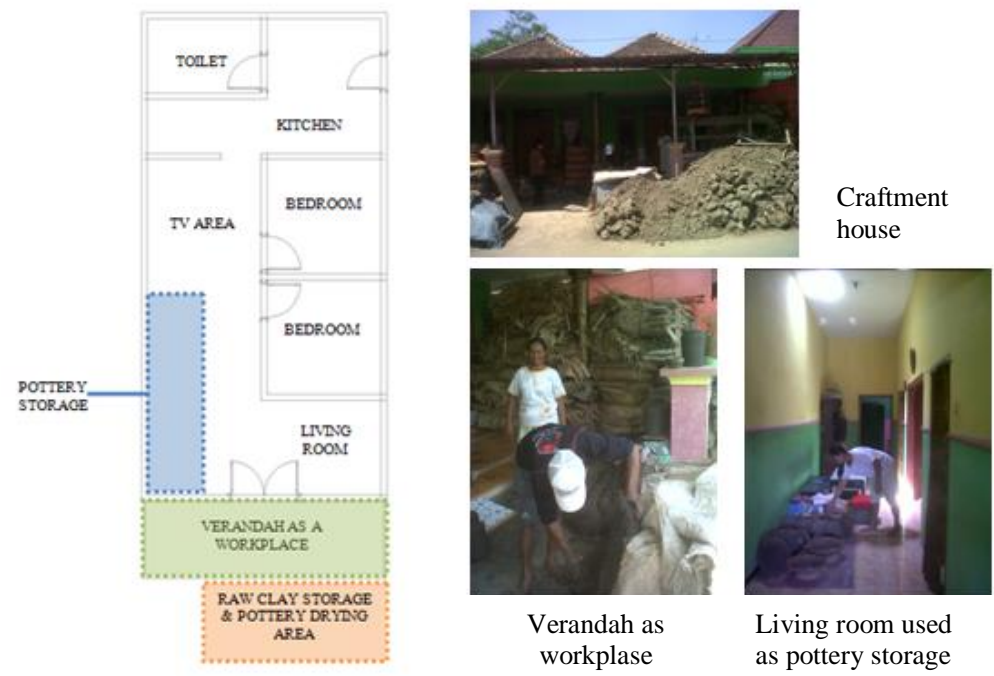

Figure 8. Mixed Type

Source: personal documentation, 2012

Beside three house types described above, In Dukuh Krajan there's another type founded, this type is pottery collector house. The function of pottery collector house is to collect pottery product from the craftmen, and there's no pottery-making activity in the house. Pottery buyer in small or big scale buy the product at collector house. In pottery collector house there's a special room for pottery products storage. There's also a truck garage, truck used by pottery collector for pottery delivery in large scale. Pottery collector use their verandah and yard both as pottery drying area and as showroom to display pottery product. By using verandah and yard as showroom it makes the buyer easier to see pottery products in detail. In Dukuh Krajan there are 4 pottery collector for 63 pottery craftmen.

Table 3. Area, Role, Activity Chart of Pottery Collector House

\begin{tabular}{llllll}
\hline Area & Roles & Roles implication & Activity & Tools & Timeframe \\
\hline Pottery & Collector & Need to be & Storage for & Wheelba & Supply of \\
storage & & considered about & pottery products & rrow & Pottery \\
& & security and & collected from the & ,wood & product \\
& & accesibility to move & craftmen & shelves, & from \\
& pottery from & & bamboo & craftmen \\
& & storage to truck. & & basket & about once \\
& & & & in a week
\end{tabular}


Table 3. Continue

\begin{tabular}{|c|c|c|c|c|c|}
\hline Area & Roles & Roles implication & Activity & Tools & Timeframe \\
\hline $\begin{array}{l}\text { Truck } \\
\text { garage }\end{array}$ & Collector & $\begin{array}{l}\text { need close access to } \\
\text { pottery storage to } \\
\text { facilitate products } \\
\text { transfer. }\end{array}$ & $\begin{array}{l}\text { Truck garage that } \\
\text { being used to } \\
\text { distribute pottery } \\
\text { product }\end{array}$ & Truck & $\begin{array}{l}\text { Pottery } \\
\text { product } \\
\text { distribution } \\
\text { using truck } \\
\text { about once } \\
\text { in a week. }\end{array}$ \\
\hline $\begin{array}{l}\text { Pottery } \\
\text { product } \\
\text { showroo } \\
\mathrm{m}\end{array}$ & $\begin{array}{l}\text { Collector } \\
\text { buyer }\end{array}$ & $\begin{array}{l}\text { In existing, pottery } \\
\text { collectors use their } \\
\text { verandah as a sho- } \\
\text { wroom for their } \\
\text { product. Showroom } \\
\text { is important part at } \\
\text { collector house and } \\
\text { should be designed } \\
\text { well, because thro- } \\
\text { ugh showroom } \\
\text { buyer can see the } \\
\text { pottery product in } \\
\text { detail. Hence, } \\
\text { showroom also } \\
\text { need close acces } \\
\text { with the road. }\end{array}$ & $\begin{array}{l}\text { Area for display } \\
\text { the product so the } \\
\text { buyer can see the } \\
\text { pottery product in } \\
\text { detail. }\end{array}$ & $\begin{array}{l}\text { Wood } \\
\text { shelves }\end{array}$ & $\begin{array}{l}\text { Every day } \\
\pm 07.00 \mathrm{AM} \\
-05.00 \mathrm{PM}\end{array}$ \\
\hline
\end{tabular}

Source: adapted from table Area, Role, Activity Chart, Heimsath, 1977

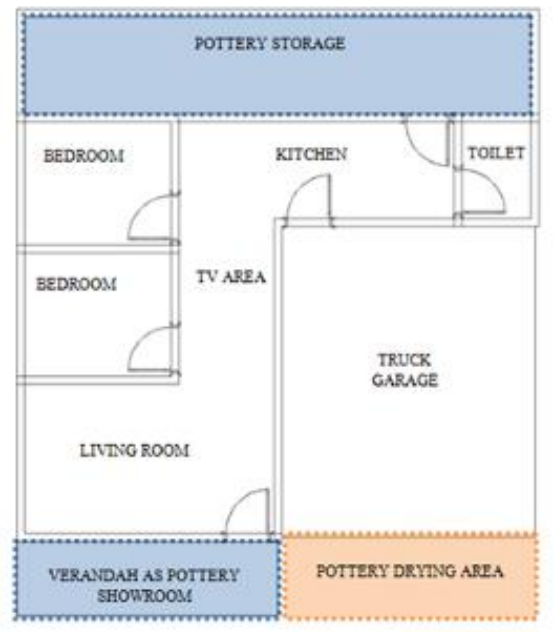

Figure 9. Pottery Collector House

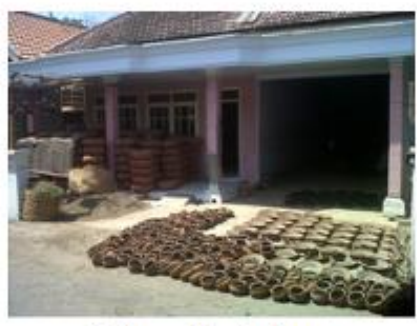

Pottery collector house

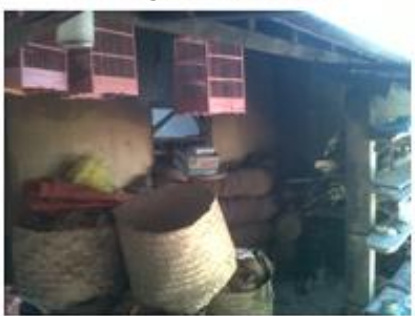

Pottery storage

Source: personal documentation,2012 


\section{CONCLUSIONS}

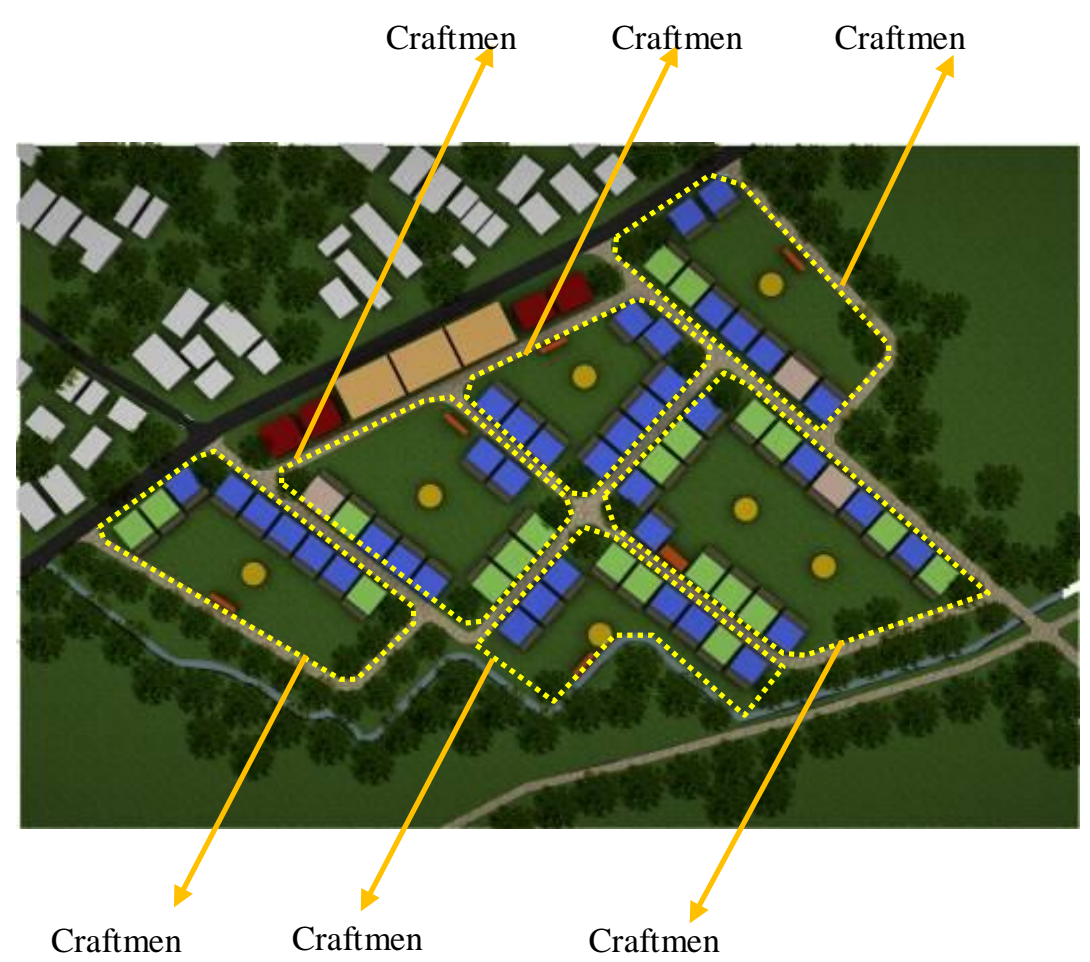

\section{NOTES :}

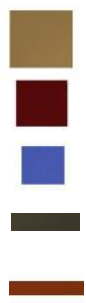

pottery central

pottery collector

mixed type

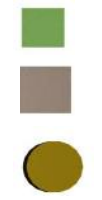

balanced type

separated type

workplace

pottery kiln

straw and bamboo mat storage

Figure 10. Block Plan Recommendation Source: personal documentation, 2012

Through behavioral analysis and existing observation described previously, there are some design reccomendation that can be applied in Dukuh Krajan :

1. Selecting craftmen activity that can be done together, which are pottery drying area, kiln, and also storage for straw and bambo.Then these activities gathered in communal open space inside the settlement.

2. Creating craftmen cluster, each cluster has 9-10 craftmen. Settlement orientation created based on Rapoport (1977) which is along the street orientation. By $4 \mathrm{~m}$ width street inside the settlement, material and product distibution expected to work smoothly. 
Every cluster facilitated with communal open space as their backyards that can be used for pottery drying area, kiln, and storage for straw and bamboo mat.

3. Space between the houses is about 1.5 meter to make sure every house has optimum natural lighting and ventilation.

4. Moving craftmen workplace in back part of the house, so the craftmen work places have close access with the communal open space.

Craftmen workplace can be either attached or detached from the house.With separation domestic needs in front part and economy needs (craftmen activity) in back part of the house, space conflicts between domestic and economy needs expected to be decreased.

5. Pottery collector house placed along the highway to facilitate pottery product distribution. For design recommendation, existence of pottery central gallery is needed to display pottery product. Through pottery central gallery buyer can see the product in details and by this gallery is hopefully can increase pottery sales.

\section{REFERENCES}

Groat, Linda and Wang, D. (2002), Architectural Research Methods, John Willey \& Sons, Canada.

Heimsath, Clovis AIA (1977), Behavioral Architecture, New York, Mc.Graw-Hill Book Company.

Rapoport, A. (1993), Development, Culture, Change and Supportive Design, USA, University of Wisconsin-Milwaukee.

Silas, J. (2000). "Rumah Produktif Pendekatan Tradisi dan Masyarakat", in Rumah Produktif, eds. Silas, J., Wibowo, A. S., Setiawan, W., Laboratorium Perumahan dan Permukiman, Surabaya.

Skinner, B.F. (1957), Verbal Behavior, Cambridge, MA, Pretince Hall.

Spradley, James P. (1997), Metode Etnografi, terjemahan oleh: Misbah Zulfa Elizabeth, PT Tiara Wacana, Yogyakarta. 